Check for updates

Cite this: RSC Adv., 2017, 7, 52017

Received 31st October 2017 Accepted 1st November 2017

DOI: 10.1039/c7ra11976c

rsc.li/rsc-advances

\section{A sustainable approach to separate and recover indium and tin from spent indium-tin oxide targets $\uparrow$}

\author{
Shuai Gu, (D) *a Bitian Fu, (D) ${ }^{b}$ Gjergj Dodbiba, ${ }^{a}$ Toyohisa Fujita ${ }^{a}$ and Baizeng Fang (DD *c
}

This study proposed an innovative method to separate and recover indium and tin from spent indium-tinoxide (ITO) targets. ITO was first dissolved using concentrated $\mathrm{HCl}$ and then the leaching solution was distilled to recycle $\mathrm{HCl}$ and crystallize indium and tin ions. Next, the obtained crystals were transferred into $\mathrm{SOCl}_{2}$ solution under refluxing to remove the crystal water. By simply fractionating the mixture, anhydrous indium chloride, tin tetrachloride, and $\mathrm{SOCl}_{2}$ can be separated in a single operation. The recovery rate of $\mathrm{InCl}_{3}$ was ca. $99.6 \%$ with a purity of ca. $99.8 \%$, while ca. $98.0 \%$ of $\mathrm{SnCl}_{4}$ was recovered with a purity of ca. $99.7 \%$. Both the recovery rates and purities are the highest reported so far. Since all the reagents used in this process were carefully designed, almost all of the reagents can be reused. This is an environmentally friendly, economical and practical method to efficiently recycle ITO targets.

\section{Introduction}

Indium-tin oxide (ITO) is a conductive solid with the characteristics of transparency and colorlessness. The excellent electrical conductivity, optical transparency and thermal reflection of ITO make it an ideal material for flat-panel displays, ${ }^{1-6}$ solar cells, ${ }^{7-9}$ organic light-emitting diodes, ${ }^{\mathbf{1 0}, 11}$ anti-static coatings, ${ }^{\mathbf{1 2}}$ electromagnetic shielding, ${ }^{13}$ and so on. Approximately $65 \%$ of indium production worldwide was consumed in the configuration of ITO, while the majority of ITO was used in coating materials for displays. ITO targets are composed of $\operatorname{In}_{2} \mathrm{O}_{3}$ and $\mathrm{SnO}_{2}$ with a mass ratio of $10 \mathrm{wt} \%, 5 \mathrm{wt} \%$, or $3 \mathrm{wt} \% \mathrm{SnO}_{2} \cdot{ }^{14}$ ITO films are synthesized by sputtering ITO targets. According to the United States Geological Survey, in the sputtering process, only $15 \%$ of ITO was utilized to make LCDs. ${ }^{15}$ Target utilization (TU) for a planar target was $c a .30 \%,{ }^{\mathbf{1 6 , 1 7}}$ while the TU for a rotary target was around $70-80 \% .^{17,18}$ It's obvious that the spent ITO targets should be recovered. Of course, the spent targets can be easily recycled for producing new ITO layers by grinding them into fine powder and mixing them with fresh ITO powder. Nevertheless, it is still of great significance to separate indium

${ }^{a}$ Graduate School of Engineering, The University of Tokyo, 113-8656, Japan. E-mail: gushuai10084627@gmail.com

${ }^{b}$ School of Ecological and Environmental Sciences, East China Normal University, Shanghai 200241, China

'Department of Chemical \& Biological Engineering, University of British Columbia, 2360 East Mall, Vancouver, B.C., V6T 1Z3, Canada.E-mail: bfang@chbe.ubc.ca

$\dagger$ Electronic supplementary information (ESI) available: Photographs for the spent ITO target materials, the recovered mixed crystal hydrates of $\mathrm{InCl}_{3}$ and $\mathrm{SnCl}_{4}$, the setup of dehydrating process, and the as-filtrated anhydrous $\mathrm{InCl}_{3}$ and $\mathrm{SnCl}_{4}$, and XRD patterns of the hydrate obtained from $\mathrm{SnCl}_{4}-\mathrm{HCl}$ solution and the standard $\mathrm{SnCl}_{4} \cdot 5 \mathrm{H}_{2} \mathrm{O}$ crystal. See DOI: $10.1039 / \mathrm{c} 7 \mathrm{ra} 11976 \mathrm{c}$ from spent ITO targets, due to the continuously growing demands for indium, gallium, and zinc oxide (IGZO), ${ }^{\mathbf{1 9 , 2 0}}$ copper, indium, gallium, and selenium (CIGS), etc. ${ }^{21}$ IGZO, a better semiconducting material, which was considered to be the most promising thin-film transistor for the next generation flat panel displays, has shown great potential for replacing ITO. ${ }^{22,23}$ At present, there are mainly five methods to separate and recycle indium from spent ITO targets: vacuum-chlorinated separation, ${ }^{24,25}$ vacuum carbonization reduction, ${ }^{26}$ solvent extraction separation, ${ }^{27-29}$ ion-exchange, ${ }^{30,31}$ and biological metallurgy separation. ${ }^{32}$

In our previous study, $\mathrm{HCl}$ gas was utilized to react with $\operatorname{In}_{2} \mathrm{O}_{3}$ and $\mathrm{SnO}_{2}$ at $373 \mathrm{~K}$ for $60 \mathrm{~min}$ to obtain $\mathrm{InCl}_{3}$ and $\mathrm{SnCl}_{4}{ }^{25}$ The reaction products $\left(\mathrm{SnCl}_{4}\right.$ and $\left.\mathrm{InCl}_{3}\right)$ were recycled respectively in a nitrogen atmosphere at $573 \mathrm{~K}$ and $673 \mathrm{~K}$ by evaporation. He et al. ${ }^{26}$ recycled ITO via a carbon (50 wt\%) reduction at $1223 \mathrm{~K}$ under $1 \mathrm{~Pa}$ for $30 \mathrm{~min}$, and pure indium could be selectively recovered around the condensing temperature. Yang et $a .^{27}$ studied the recovery of indium using extractants cyanex 923, cyanex 272, TBP and D2EHPA, respectively in hydrochloric and sulfuric acid solution, and $c a$. $99 \mathrm{wt} \%$ of indium was recovered with a purity around $90 \%$. Swain et al. ${ }^{28}$ reported a recovery rate of $97.78 \%$ for Sn with $99 \%$ purity by using the extractant cyanex 272.28 LópezDíaz-Pavón et $a .^{31}$ utilized the cationic ionexchange resin Lewatit K-2621 to separate indium from tin. Higashi et al. ${ }^{32}$ recovered indium by adding the Shewanella algae into the leached solution to concentrate the indium for 680 times. Unfortunately, all these methods mentioned above suffer from their own drawbacks, namely, vacuum-chlorinated separation has relatively low recovery rate and operates at high temperature, vacuum carbonization reduction process operates at even higher temperature and low pressure; solvent extraction 
consumes lots of water and organic reagents; ion-exchange and biological metallurgy are hard to operate in large scale. ${ }^{33}$ Based on this, an innovative sustainable approach to separate and recover indium and tin efficiently is highly desired. In this study, a scalable, economical and sustainable approach, dissolutiondistillation-dehydration-fractionation (DDDF), has been developed. The recovery rates and purities of $\mathrm{InCl}_{3}$ and $\mathrm{SnCl}_{4}$ are the highest reported so far, indicating this approach is very promising for practical application.

\section{Experimental section}

\subsection{Materials and methods}

The spent ITO target material (Wako chemicals), was first ground to fine powder, as shown in Fig. S1 (ESI†) for composition analysis. The physical properties of the spent ITO powder (density, size distribution) are described in the ESI. $\dagger$ The composition of the spent ITO targets were examined by XRF (Rigaku supermini WDXRF) and the mass fraction of each component in the ITO target was measured by standard FP quantification program (SQX) analysis, and the data are shown in Table 1 . Since SQX is only a semi-quantitative analysis method, the actual mass fraction of indium and tin in the spent target was determined by ICP-OES (PerkinElmer® Optima 5300 DV) after dissolving the ITO target powder using aqua regia. Table S1 (ESI $\dagger$ ) summarizes the mass of $\mathrm{In}^{3+}, \mathrm{Sn}^{4+}$, and $\mathrm{Zn}^{2+}$ determined by ICP-OES for three ITO powder samples with different masses. The average mass fraction for these species is also shown in Table 1, from which it is clear that the mass ratio of $\mathrm{In}_{2} \mathrm{O}_{3}$ to $\mathrm{SnO}_{2}$ is around $95: 5$ with $\mathrm{ZnO}$ as the main impurity.

The DDDF separation and recovery process is shown in Scheme 1. The process can be divided into four steps: dissolution, distillation or crystallization, dehydration, and fractionation. First, the spent ITO powder was dissolved completely with $\mathrm{HCl}$, and then the leached solution was distilled to obtain the crystal of metal chloride hydrates. Next, the crystal was dehydrated by a dehydrating agent (i.e., $\mathrm{SOCl}_{2}$ ) under refluxing. Last, the resultant solution was fractionated to separate anhydrous $\mathrm{InCl}_{3}, \mathrm{SnCl}_{4}$, and $\mathrm{SOCl}_{2}$. For a typical separation and recovery process, ITO target powder was first dissolved by concentrated $\mathrm{HCl}$, and indium and tin oxides in the ITO were dissolved into the leaching solution. The distillation process was conducted in a rotary evaporator equipped with an oil bath and a vacuum pump. After distillation, the mixture of indium chloride and tin chloride hydrates were left in the bottom of the flask. The mixed hydrates were then transferred into a flask, followed by the addition of an appropriate amount of $\mathrm{SOCl}_{2}$ for dehydrating. Because the dehydration process required refluxing $\mathrm{SOCl}_{2}$, the flask was equipped with a condenser-Allihn type

Table 1 The chemical composition of the spent ITO target determined by SQX analysis of XRF and ICP-OES

\begin{tabular}{lllll}
\hline Composition by XRF & $\mathrm{In}_{2} \mathrm{O}_{3}$ & $\mathrm{SnO}_{2}$ & $\mathrm{ZnO}$ & Others \\
Mass (wt\%) & 94.92 & 4.94 & 0.12 & 0.02 \\
Composition by ICP & $\mathrm{In}^{3+}$ & $\mathrm{Sn}^{4+}$ & $\mathrm{Zn}^{2+}$ & \\
Mass (wt\%) & 95.17 & 4.71 & 0.12 &
\end{tabular}

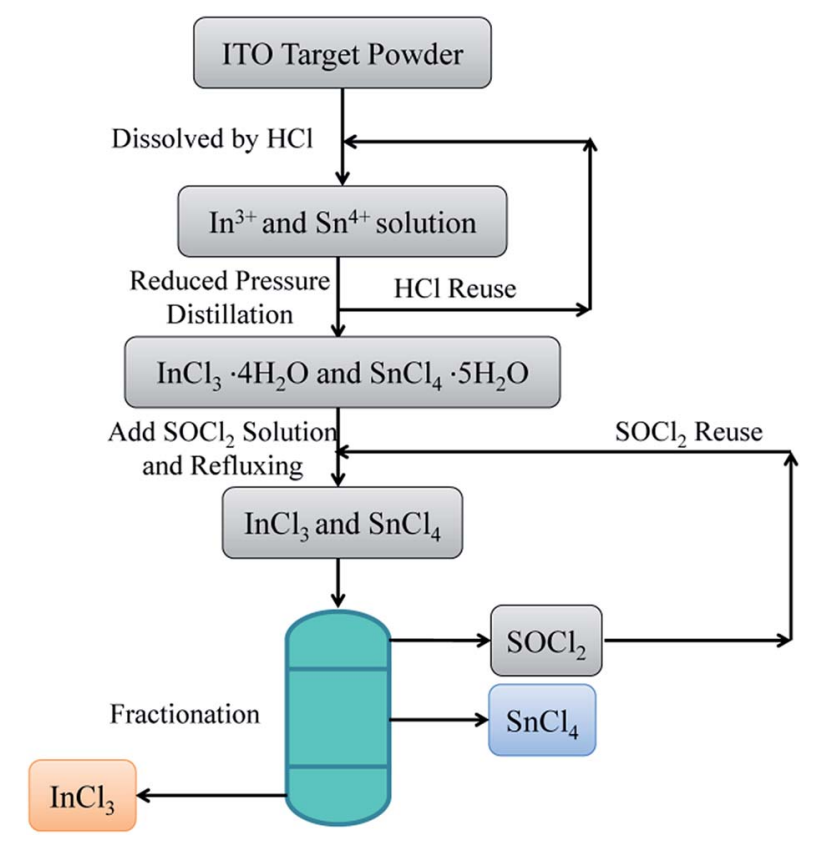

Scheme 1 Illustration of the green approach to separate indium and tin from the spent ITO target.

and a mandarin heater. During this step, the crystal water in indium chloride and tin chloride hydrates reacted with $\mathrm{SOCl}_{2}$, leaving the anhydrous $\mathrm{InCl}_{3}$ and $\mathrm{SnCl}_{4}$ in the solution. It is well known that anhydrous $\mathrm{SnCl}_{4}$ is a liquid at room temperature. Anhydrous $\mathrm{InCl}_{3}$ has no/little solubility in both $\mathrm{SnCl}_{4}$ and $\mathrm{SOCl}_{2}$, while $\mathrm{SnCl}_{4}$ has a considerable solubility in $\mathrm{SOCl}_{2}$ solution as shown in eqn (1): ${ }^{34}$

$$
2 \mathrm{SOCl}_{2}+\mathrm{SnCl}_{4} \rightleftharpoons 2 \mathrm{SOCl}^{+}+\mathrm{SnCl}_{6}{ }^{2-}
$$

In the fourth step, anhydrous $\mathrm{InCl}_{3}, \mathrm{SnCl}_{4}$, and $\mathrm{SOCl}_{2}$ can be separated from each other by simply fractionating the mixture. $\mathrm{SOCl}_{2}$, which has the lowest boiling point around $76{ }^{\circ} \mathrm{C}$, was removed from the mixture first. After that, $\mathrm{SnCl}_{4}$ was also removed at approximately $114{ }^{\circ} \mathrm{C}$. At last, anhydrous $\mathrm{InCl}_{3}$ powder (melting point: $586^{\circ} \mathrm{C}$, boiling point: $800^{\circ} \mathrm{C}$ ) was left at the bottom of the flask. The hydrates of indium chloride and tin chloride from the distillation process and the anhydrous $\mathrm{InCl}_{3}$ from the fractionation process were then analyzed with XRD (Rigaku® Smart lab). Since indium chloride hydrate, tin chloride hydrate, and anhydrous indium chloride are sensitive to the moisture in the air, an air-sensitive sample holder (Rigaku ${ }^{\circledR}$ Mini Flex accessories) was utilized to isolate the samples from the air during the XRD measurements.

\subsection{HCl leaching}

The spent ITO target was crushed and milled to fine powder with an average particle size of around $6.781 \mu \mathrm{m}$, as shown in Fig. S2 (ESI $\dagger$ ). The powder was then dissolved in $\mathrm{HCl}$ solution under different acid concentrations, solid-liquid (S/L) ratios, temperatures, and leaching times. The concentration of $\mathrm{HCl}$ 
was varied from $1 \mathrm{~mol} \mathrm{~L}{ }^{-1}$ to $9 \mathrm{~mol} \mathrm{~L}^{-1}$ (i.e., 1, 3, 5, 7, and $9 \mathrm{~mol} \mathrm{~L}^{-1}$ ) with an $\mathrm{S} / \mathrm{L}$ ratio ranging from $1 \mathrm{~g} \mathrm{~L}^{-1}$ to $20 \mathrm{~g} \mathrm{~L}^{-1}$ (i.e., $1,5,10$, and $\left.20 \mathrm{~g} \mathrm{~L}^{-1}\right)$. The leaching temperature was varied from $20{ }^{\circ} \mathrm{C}$ to $90{ }^{\circ} \mathrm{C}$ (i.e., 20, 40, 60, 80, and $90{ }^{\circ} \mathrm{C}$ ) with the leaching time ranging from $30 \mathrm{~min}$ to $120 \mathrm{~min}$ (i.e., 30, 50, 70, 90, and $120 \mathrm{~min})$. The leaching process was conducted in a beaker equipped with a stirring hotplate (RET control-visc, IKA) to control the stirring speed and leaching temperature. $\mathrm{HCl}$ (37\%, reagent grade, Sigma-Aldrich) was used as received.

\subsection{Distillation, dehydration, and fractionation}

The leached solution was then transferred to a rotary evaporator (Eyela $\left.{ }^{\circledR N}-1100 \mathrm{D}\right)$ equipped with an oil bath operated at $90{ }^{\circ} \mathrm{C}$ and a vacuum pump (Eyela ${ }^{\circledR N V C-2200)}$ with a vacuum degree of $0.09 \mathrm{MPa}$ for $2 \mathrm{~h}$. After that, the hydrates remained at the bottom of the flask were transferred to a new flask equipped with a mandarin heater and a condenser for dehydration. $\mathrm{SOCl}_{2}$ (99.5\%, analytical pure, Sigma-Aldrich) was used as received. The ratio of $\mathrm{SOCl}_{2}$ to hydrate was $1.2 \mathrm{~mL} \mathrm{~g}^{-1}$. $\mathrm{SOCl}_{2}$ was refluxed at $75{ }^{\circ} \mathrm{C}$ for $2 \mathrm{~h}$ to dehydrate the mixture. During this process, $\mathrm{SO}_{2}$ and $\mathrm{HCl}$ gas kept bubbling out of the solution till the dehydration process reached the ending point. After the bubbling stopped, the fractionation process started. The flask was equipped with a Vigreux fractionating column to separate $\mathrm{SOCl}_{2}$ and anhydrous $\mathrm{SnCl}_{4}$ at $114{ }^{\circ} \mathrm{C}$ for $2 \mathrm{~h}$ (Fig. S7, ESI $\dagger$ ) through which $\mathrm{SOCl}_{2}$ was distilled out of the flask, leaving anhydrous $\mathrm{SnCl}_{4}$ and $\mathrm{InCl}_{3}$ at the bottom of the flask. At last, anhydrous $\mathrm{SnCl}_{4}$ was also distilled out of the flask and thus separated from $\mathrm{InCl}_{3}$.

\section{Results and discussion}

\subsection{Dissolution of the spent ITO targets}

The optimum leaching condition was investigated by dissolving the spent ITO target in various HCl-based solvents with different acid concentrations, $\mathrm{S} / \mathrm{L}$ ratios, temperatures, and times. The stirring rate was fixed at $500 \mathrm{rpm}$ (peripheral velocity: $31.4 \mathrm{~cm} \mathrm{~s}^{-1}$ ). As can be seen from Fig. 1, the mixed solvent composed of $5 \mathrm{M} \mathrm{HCl}$ with an $\mathrm{S} / \mathrm{L}$ ratio of $10 \mathrm{~g} \mathrm{~L}^{-1}$ and leaching temperature of $40{ }^{\circ} \mathrm{C}$ all indium and tin could be dissolved after $120 \mathrm{~min}$. The leaching results of the optimum condition are given in Table 2, which shows that more than $99.9 \%$ of indium and tin can be dissolved (Table S1, ESI $\dagger$ ). The main impurities are zinc and aluminum.

\subsection{Distillation and dehydration process}

After the dissolution step, the leaching solution was distilled to recycle $\mathrm{HCl}$. In addition, a mixed hydrate crystal was obtained in this step, which was analyzed with XRD and ICP-OES. For some reason we do not have the standard card info of $\mathrm{InCl}_{3} \cdot 4 \mathrm{H}_{2} \mathrm{O}$, and thus, the obtained XRD pattern was compared with $\mathrm{InCl}_{3} \cdot 4 \mathrm{H}_{2} \mathrm{O}$ and $\mathrm{SnCl}_{4} \cdot 5 \mathrm{H}_{2} \mathrm{O}$. The details about the preparation of the hydrate metal chloride can be seen from the ESI $\uparrow$ and the XRD patterns for the standard $\mathrm{SnCl}_{4} \cdot 5 \mathrm{H}_{2} \mathrm{O}$ crystal and as-distilled $\mathrm{SnCl}_{4}$ hydrate are shown in Fig. S3 (ESI $\dagger$ ). As can be seen from Fig. 2, all of the characteristic peaks in
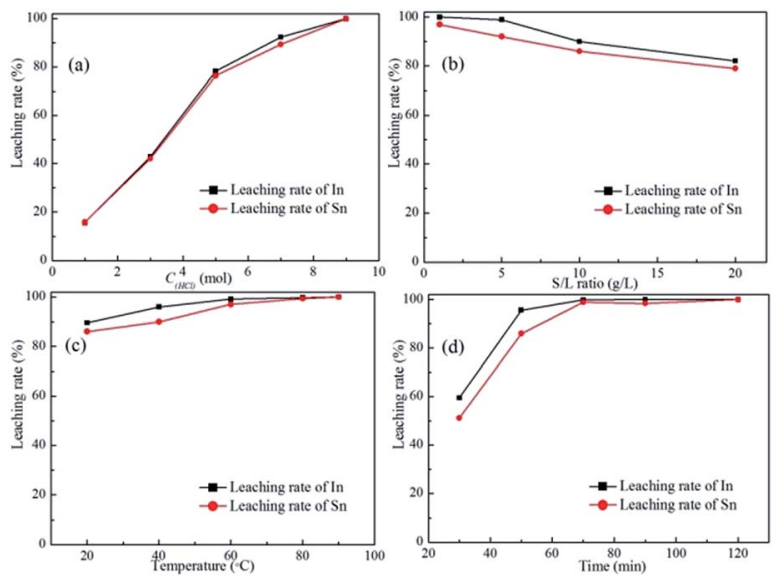

Fig. 1 Leaching of the spent ITO target under different conditions: (a) the effect of $\mathrm{HCl}$ concentration on the leaching rate of ITO target with the temperature of $20^{\circ} \mathrm{C}$, the leaching time of $60 \mathrm{~min}$, and the $\mathrm{S} / \mathrm{L}$ ratio of $20 \mathrm{~g} \mathrm{~L}^{-1}$, (b) the effect of $\mathrm{S} / \mathrm{L}$ ratio on the leaching rate of ITO target with the temperature of $20^{\circ} \mathrm{C}$, the leaching time of $60 \mathrm{~min}$, and $\mathrm{HCl}$ concentration of $5 \mathrm{~mol} \mathrm{~L}^{-1}$, (c) the effect of leaching temperature on the leaching rate of ITO target with the leaching time of $60 \mathrm{~min}$, the $\mathrm{S} / \mathrm{L}$ ratio of $10 \mathrm{~g} \mathrm{~L}^{-1}$, and $\mathrm{HCl}$ concentration of $5 \mathrm{~mol} \mathrm{~L}^{-1}$, and (d) the effect of leaching time on the leaching rate of ITO target with the temperature of $40^{\circ} \mathrm{C}$, the $\mathrm{S} / \mathrm{L}$ ratio of $10 \mathrm{~g} \mathrm{~L}^{-1}$, and $\mathrm{HCl}$ concentration of $5 \mathrm{~mol} \mathrm{~L}^{-1}$

Table 2 The chemical composition of the spent ITO target powder obtained from leaching

\begin{tabular}{llllll}
\hline $\begin{array}{l}\text { ITO powder } \\
(\mathrm{g})\end{array}$ & $\begin{array}{l}\mathrm{In}^{3+} \\
(\mathrm{ppm})\end{array}$ & $\begin{array}{l}\mathrm{Sn}^{4+} \\
(\mathrm{ppm})\end{array}$ & $\begin{array}{l}\mathrm{Zn}^{2+} \\
(\mathrm{ppm})\end{array}$ & $\begin{array}{l}\mathrm{Al}^{3+} \\
(\mathrm{ppm})\end{array}$ & Others \\
\hline 3.275 & 8570 & 425 & 10.5 & 2.44 & $<1 \mathrm{ppm}$ \\
3.158 & 8263 & 429 & 10.1 & 2.35 & $<1 \mathrm{ppm}$ \\
3.098 & 8106 & 402 & 9.93 & 2.31 & $<1 \mathrm{ppm}$ \\
\hline
\end{tabular}

$\mathrm{InCl}_{3} \cdot 4 \mathrm{H}_{2} \mathrm{O}$ and $\mathrm{SnCl}_{4} \cdot 5 \mathrm{H}_{2} \mathrm{O}$ patterns appeared in the asdistilled mixed hydrate crystal pattern except that few peaks with very low intensity were observed for the as-distilled mixed hydrate crystal but these peaks did not appear in both $\mathrm{InCl}_{3}$ $\cdot 4 \mathrm{H}_{2} \mathrm{O}$ and $\mathrm{SnCl}_{4} \cdot 5 \mathrm{H}_{2} \mathrm{O}$, implying that these weak peaks are probably attributed to the characteristic peaks of the impurities in the spent ITO target material. Therefore, the main composition of the mixed crystal should be $\mathrm{InCl}_{3} \cdot 4 \mathrm{H}_{2} \mathrm{O}$ and $\mathrm{SnCl}_{4} \cdot 5 \mathrm{H}_{2} \mathrm{O}$. Based on this, the ratio of indium and tin hydrate can be calculated by dissolving a certain amount of the asdistilled mixed crystal (as shown in Fig. S3, ESI $\dagger$ ) and analyzing with ICP-OES. The mixed crystal obtained in this step was determined to contain $94.38 \mathrm{wt} \% \quad \mathrm{InCl}_{3} \cdot 4 \mathrm{H}_{2} \mathrm{O}$ and 5.53 wt $\% \mathrm{SnCl}_{4} \cdot 5 \mathrm{H}_{2} \mathrm{O}$ (Table $\mathrm{S} 2, \mathrm{ESI} \dagger$ ). In order to separate indium from tin, $\mathrm{SOCl}_{2}$ was added to dehydrate the crystal, and as a result, anhydrous $\mathrm{InCl}_{3}$ and $\mathrm{SnCl}_{4}$ can be obtained according to eqn (2) and (3). ${ }^{35}$ According to the composition of the hydrate obtained from XRD and ICP-OES, $1 \mathrm{~g}$ hydrate contains $0.9438 \mathrm{~g} \mathrm{InCl}_{3} \cdot 4 \mathrm{H}_{2} \mathrm{O}$ and $0.0553 \mathrm{~g} \mathrm{SnCl}_{4} \cdot 5 \mathrm{H}_{2} \mathrm{O}$, which means $1 \mathrm{~g}$ hydrate would consume $0.991 \mathrm{ml}$ of $\mathrm{SOCl}_{2}$ solution. To ensure a thorough dehydration, the $\mathrm{S} / \mathrm{L}$ ratio of the crystal 


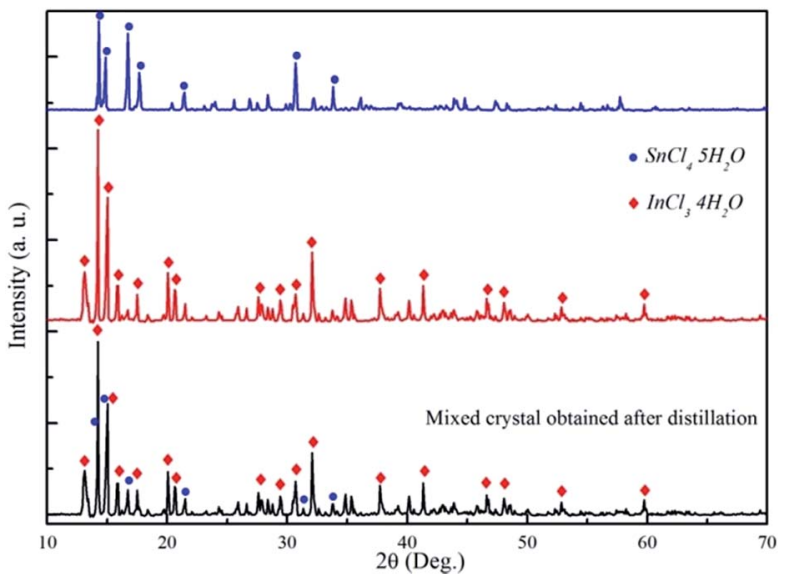

Fig. 2 XRD patterns of the mixed hydrate crystal obtained after distillation, $\mathrm{InCl}_{3} \cdot 4 \mathrm{H}_{2} \mathrm{O}$, and $\mathrm{SnCl}_{4} \cdot 5 \mathrm{H}_{2} \mathrm{O}$.

hydrate and $\mathrm{SOCl}_{2}$ was set as $1 \mathrm{~g} / 1.2 \mathrm{ml}$. $\mathrm{HCl}$ and $\mathrm{SO}_{2}$ gases were emitted during the dehydration process, which are hazardous to the environment. Proper methods were adopted to separate or dispose these hazardous gases. By utilizing the different solubility of $\mathrm{HCl}$ and $\mathrm{SO}_{2}$ in water, the majority of $\mathrm{HCl}$ can be separated from $\mathrm{SO}_{2}$ in hot water. ${ }^{36}$ After which, $\mathrm{HCl}$ can be used in the leaching process, while $\mathrm{SO}_{2}$ can be liquefied for storage and sale (Table $\mathrm{S} 3, \mathrm{ESI}+$ ). $\mathrm{HCl}$ and $\mathrm{SO}_{2}$ gases can also be disposed with $\mathrm{Ca}(\mathrm{OH})_{2}$ etc. in the dry scrubbing process ${ }^{37,38}$ (Table S3, ESI $\dagger$ ). The setup for dehydrating is shown in Fig. S5 $(\mathrm{ESI} \dagger)$.

$$
\begin{gathered}
\mathrm{InCl}_{3} \cdot 4 \mathrm{H}_{2} \mathrm{O}+4 \mathrm{SOCl}_{2} \rightarrow \mathrm{InCl}_{3}+4 \mathrm{SO}_{2} \uparrow+8 \mathrm{HCl} \uparrow \\
\mathrm{SnCl}_{4} \cdot 5 \mathrm{H}_{2} \mathrm{O}+5 \mathrm{SOCl}_{2} \rightarrow \mathrm{SnCl}_{4}+5 \mathrm{SO}_{2} \uparrow+10 \mathrm{HCl} \uparrow
\end{gathered}
$$

\subsection{Fractionation process}

After dehydrating, the mixture of anhydrous $\mathrm{SnCl}_{4}$ and $\mathrm{SOCl}_{2}$ was heated for fractionation. Since anhydrous $\mathrm{InCl}_{3}$ is insoluble in $\mathrm{SnCl}_{4}$ and $\mathrm{SOCl}_{2}$ (Fig. S6, $\mathrm{ESI} \dagger$ ), the fractionation process would not be affected by the appearance of anhydrous $\mathrm{InCl}_{3}$. Fig. 3 shows the binary liquid-liquid phase diagram of anhydrous $\mathrm{SnCl}_{4}$ and $\mathrm{SOCl}_{2}$. The molar ratio of anhydrous $\mathrm{SnCl}_{4}$ in the solution was $2.2 \%$ at this point. With the distilling of $\mathrm{SOCl}_{2}$, the molar ratio of anhydrous $\mathrm{SnCl}_{4}$ kept increasing. At last, almost all $\mathrm{SOCl}_{2}$ was vaporized into the gas phase, which required 5 theoretical plates to reach $99.9 \%$ pure of $\mathrm{SOCl}_{2}$, as shown in Fig. 3. Also, according to the shape of the binary phase diagram, anhydrous $\mathrm{SnCl}_{4}$ would not form azeotrope with $\mathrm{SOCl}_{2}$. Afterwards, $\mathrm{SnCl}_{4}$ can also be distilled out of the flask at around $114{ }^{\circ} \mathrm{C}$, leaving the white powder at the bottom of the flask. As shown in Fig. 4, the XRD pattern reveals that the white powder (shown in Fig. S8, ESI $\dagger$ ) was anhydrous $\mathrm{InCl}_{3}$ and the purity was $99.8 \mathrm{wt} \%$ (Table S5, ESI $\dagger$ ). To examine the recovery rate of $\mathrm{InCl}_{3}$ and $\mathrm{SnCl}_{4}$, three parallel experiments were done and analyzed with ICP-OES, and the data are shown in Table 3. The recovery rate of indium in the whole process was calculated

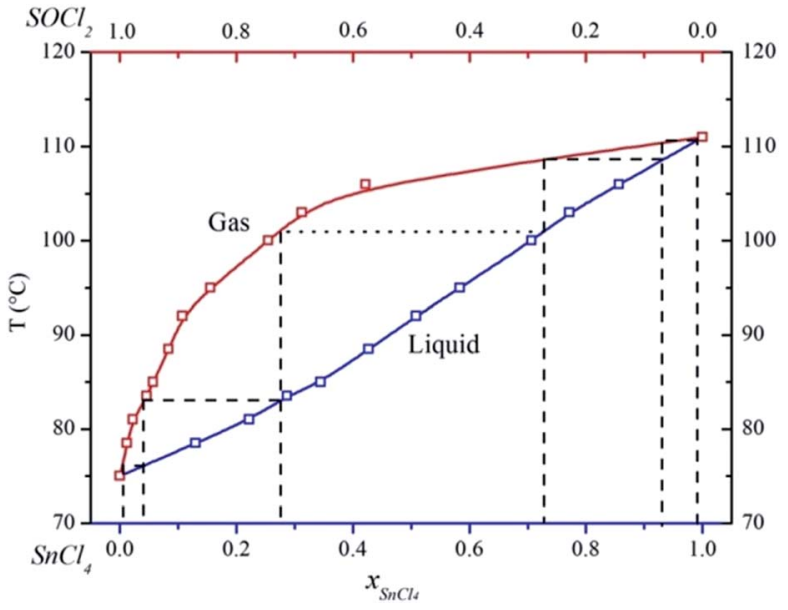

Fig. 3 Binary liquid-liquid phase diagram of anhydrous $\mathrm{SnCl}_{4}$ and $\mathrm{SOCl}_{2}$.
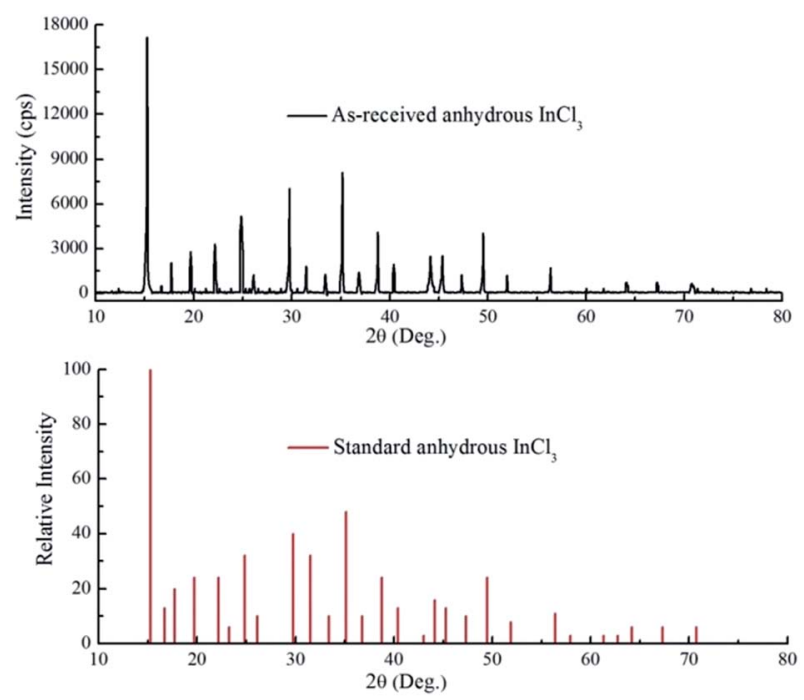

Fig. $4 \mathrm{XRD}$ patterns of the as-recovered $\mathrm{InCl}_{3}$ and the standard anhydrous $\mathrm{InCl}_{3}$.

to be approximately $99.6 \%$. Anhydrous $\mathrm{SnCl}_{4}$ was separated from $\mathrm{SOCl}_{2}$ solution by distillation due to the lower boiling point of $\mathrm{SOCl}_{2}$. $\mathrm{SnCl}_{4}$ was analyzed with ICP-OES, and the data are also shown in Table 3 . The recovery rate of tin was calculated to be around $98.5 \%$, while the purity of $\mathrm{SnCl}_{4}$ was determined to be $c a .99 .7 \%$ (Table S5, ESI $\dagger$ ).

\subsection{Comparison of DDDF with ion-exchange and solvent extraction methods}

Since vacuum chlorinated separation and vacuum carbonization reduction process operates at a high temperature (1000$1300 \mathrm{~K}$ ) and high vacuum degree (e.g., $1 \mathrm{~Pa}$ ), which requires more sophisticated equipment, and are mainly designed for the recycling of indium and tin from waste LCDs. A comparison has been made between this method with solvent extraction and ion-exchange methods to demonstrate the superiority of the 
Table 3 Recovery rate of indium and tin from spent ITO target material measured by ICP-OES

\begin{tabular}{|c|c|c|c|c|c|c|c|c|c|}
\hline \multirow[b]{2}{*}{ ITO } & \multirow{2}{*}{$\begin{array}{l}\text { Dissolution } \\
(\mathrm{g}) \\
\mathrm{In}^{3+}\end{array}$} & \multirow{2}{*}{$\begin{array}{l}\begin{array}{l}\text { Distillation } \\
(\mathrm{g})\end{array} \\
\mathrm{Sn}^{4+}\end{array}$} & \multirow{2}{*}{$\begin{array}{l}\text { Dehydration } \\
(\mathrm{g})\end{array}$} & \multirow{2}{*}{$\begin{array}{l}\text { Fractionation } \\
(\mathrm{g}) \\
\mathrm{InCl}_{3}\end{array}$} & \multicolumn{5}{|c|}{ Recovery rate (\%) } \\
\hline & & & & & $\mathrm{SnCl}_{4}$ & $\mathrm{InCl}_{3}$ & $\mathrm{SnCl}_{4}$ & $\mathrm{InCl}_{3}$ & $\mathrm{SnCl}_{4}$ \\
\hline 5.079 & 3.987 & 0.1976 & 10.77 & 7.656 & 0.4311 & 7.655 & 0.4305 & 99.67 & 99.28 \\
\hline 5.018 & 3.939 & 0.1953 & 10.64 & 7.557 & 0.4199 & 7.556 & 0.4192 & 99.58 & 97.81 \\
\hline 5.027 & 3.946 & 0.1956 & 10.66 & 7.570 & 0.4232 & 7.569 & 0.4228 & 99.57 & 98.50 \\
\hline
\end{tabular}

Table 4 Comparison of recycling $1 \mathrm{~kg}$ of ITO targets with solvent extraction, ion-exchange, and DDDF process ${ }^{a}$

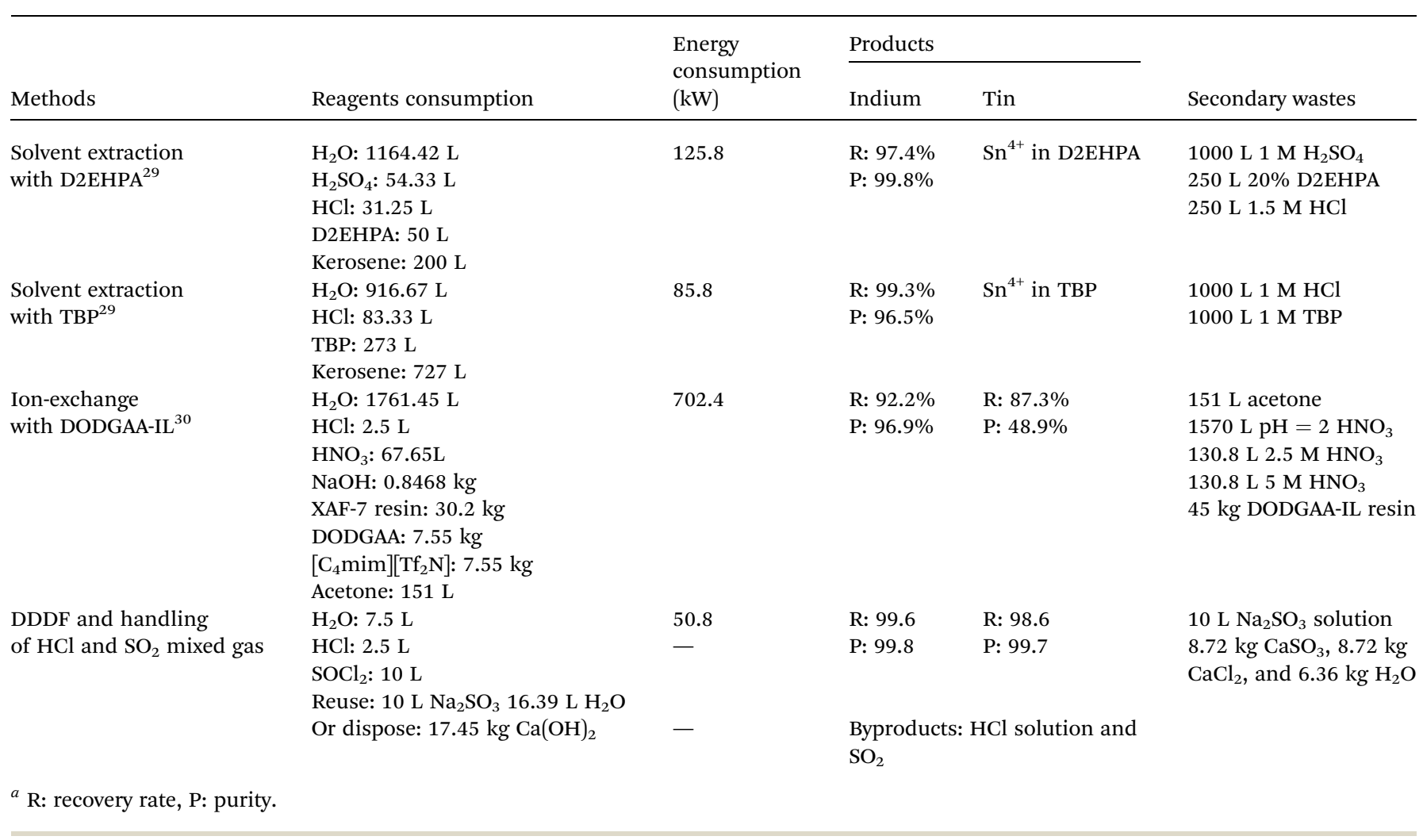

DDDF process in separate and recycle indium and tin from spent ITO targets. The evaluation was performed based on the previous reports for recycling $1 \mathrm{~kg}$ spent ITO target with solventextraction, ion-exchange and DDDF process in a laboratory scale. As shown in Table 4 which summarizes the information about the secondary wastes (Table S3, ESI $\dagger$ ), energy consumptions (Table S6, ESI $\dagger$ ), products (Table S7, ESI $\dagger$ ), and reagents consumptions (Table S8, ESI $\dagger$ ) in these processes. It's evident that the DDDF process consumes less energy, reagents, and produces the least secondary wastes with the highest recovery rate and purity of the products. While in the solvent extraction process only indium was separated and recovered, and tremendous amount of chemicals (extractants, diluents, stripping reagents) and water were consumed which generated huge amount of secondary wastes. The extractants were not counted as the secondary wastes, since they can be used multiple times. Both indium and tin can be separated and recovered with a lower recovery rate and purity in the ion-exchanged process, while an enormous amount of chemicals (extractants, ionic liquid, solvent, and resin) and water were consumed and finally became secondary wastes. In contrast, the DDDF process only requires general equipment, which makes it easy to scale up. Based on these, it's safe to say the DDDF process is a scalable, economical and sustainable approach.

\section{Conclusions}

In summary, the DDDF process developed in this study is highly efficient in separating and recovering indium and tin from spent ITO targets. By tailoring the reagents used in this process, almost all the reagents could be recycled and reused, and only sulfur dioxide and hydrogen chloride were emitted, which can also be easily collected and disposed. Compared with other processes reported previously, this method has the advantages 
such as: consuming less energy, minimizing the reagents consumption, scalable mass production, higher recovery rate, and environmental benignity. 99.6\% of indium in the form of anhydrous $\mathrm{InCl}_{3}$ with a purity of $99.8 \%$ was separated and recovered, while $98.6 \%$ of tin in the form of $\mathrm{SnCl}_{4}$ was separated and recovered, which has a purity of $99.7 \%$. The purities and recovery rates of indium and tin are the highest among all the values reported for various processes. Furthermore, a complete separation of indium and tin was achieved in a simple fractionation step. Therefore, this method has taken full advantage of the property of anhydrous $\mathrm{SnCl}_{4}, \mathrm{InCl}_{3}$, and $\mathrm{SOCl}_{2}$ to separate indium and tin from the spent ITO targets. $\mathrm{SOCl}_{2}$ plays two roles in this process: the first role is to react with $\mathrm{InCl}_{3} \cdot 4 \mathrm{H}_{2} \mathrm{O}$ and $\mathrm{SnCl}_{4} \cdot 5 \mathrm{H}_{2} \mathrm{O}$ to form anhydrous $\mathrm{InCl}_{3}$ and $\mathrm{SnCl}_{4}$, and the second role is to separate $\mathrm{InCl}_{3}$ and $\mathrm{SnCl}_{4}$ from $\mathrm{SOCl}_{2}$ due to the lowest boiling point of the latter. These important roles of $\mathrm{SOCl}_{2}$ enable the whole separation and recovery process to function efficiently. Another important reagent used in this process is $\mathrm{HCl}$, which also has two important roles: (1) the relatively low boiling point of $\mathrm{HCl}$ enables it to be reused easily by simply heating at low temperature, and (2) the crystal resulted from the heating is metal chloride hydrates, which provide a great opportunity for $\mathrm{SOCl}_{2}$ to react with them. More importantly, the final product is high purity of anhydrous $\mathrm{InCl}_{3}$ and $\mathrm{SnCl}_{4}$ rather than $\mathrm{InCl}_{3}$ and $\mathrm{SnCl}_{4}$ in aqueous solution, and thus there is no need for further procedures such as liquid-liquid extraction and ion-exchange process.

In brief, a scalable and highly efficient sustainable process has been developed to separate and recover indium and tin from spent ITO targets, which sheds light on recycling ITO targets economically.

\section{Conflicts of interest}

The authors declare no competing financial interest.

\section{Acknowledgements}

This work was supported by the China Scholarship Council (CSC) which is gratefully acknowledged.

\section{References}

1 J. Ruan, Y. Guo and Q. Qiao, Recovery of indium from scrap TFT-LCDs by solvent extraction, Procedia Environ. Sci., 2012, 16, 545-551.

2 A. V. M. Silveira, M. S. Fuchs, D. K. Pinheiro, E. H. Tanabe and D. A. Bertuol, Recovery of indium from LCD screens of discarded cell phones, Waste Manage., 2015, 45, 334-342.

3 T. Kato, S. Igarashi, Y. Ishiwatari, M. Furukawa and H. Yamaguchi, Separation and concentration of indium from a liquid crystal display via homogeneous liquidliquid extraction, Hydrometallurgy, 2013, 137, 148-155.

4 Y. H. Tak, K. B. Kim, H. G. Park, K. H. Lee and J. R. Lee, Criteria for ITO (indium-tin-oxide) thin film as the bottom electrode of an organic light emitting diode, Thin Solid Films, 2002, 411, 12-16.
5 B. H. Lee, I. G. Kim, S. W. Cho and S. H. Lee, Effect of process parameters on the characteristics of indium tin oxide thin film for flat panel display application, Thin Solid Films, 1997, 302, 25-30.

6 U. Betz, M. K. Olsson, J. Marthy, M. F. Escola and F. Atamny, Thin films engineering of indium tin oxide: large area flat panel displays application, Surf. Coat. Technol., 2006, 200, 5751-5759.

7 M. T. Dang, P. Brunner and J. Wuest, A green approach to organic thin-film electronic devices: Recycling electrodes composed of indium tin oxide (ITO), ACS Sustainable Chem. Eng., 2014, 2, 2715-2721.

8 M. T. Dang, J. Lefebvre and J. Wuest, Recycling Indium Tin Oxide (ITO) Electrodes Used in Thin-Film Devices with Adjacent Hole-Transport Layers of Metal Oxides, ACS Sustainable Chem. Eng., 2015, 3, 3373-3381.

9 J. Du, X. Chen, C. Liu, J. Ni, G. Hou, Y. Zhao and X. Zhang, Highly transparent and conductive indium tin oxide thin films for solar cells grown by reactive thermal evaporation at low temperature, Appl. Phys. A: Mater. Sci. Process., 2014, 117, 815-822.

10 H. Kim, C. Gilmore, A. Pique, J. Horwitz, H. Mattoussi, H. Murata, Z. Kafafi and D. Chrisey, Electrical, optical, and structural properties of indium-tin-oxide thin films for organic light-emitting devices, J. Appl. Phys., 1999, 86, 6451-6461.

11 H. Kim, A. Pique, J. Horwitz, H. Mattoussi, H. Murata, Z. Kafafi and D. Chrisey, Indium tin oxide thin films for organic light-emitting devices, Appl. Phys. Lett., 1999, 74, 3444-3446.

12 N. Al-Dahoudi, H. Bisht, C. Göbbert, T. Krajewski and M. Aegerter, Transparent conducting, anti-static and antistatic-anti-glare coatings on plastic substrates, Thin Solid Films, 2001, 392, 299-304.

13 Y. Sun, H. Chang, S. Wu, Y. Leng and L. Wang, Study on Electromagnetic Shielding of Infrared/Visible Optical Window, Model. Appl. Sci., 2015, 9, 231-236.

14 Y. Sato, R. Tokumaru, E. Nishimura, P. Song and Y. Shigesato, Structural, electrical, and optical properties of transparent conductive $\mathrm{In}_{2} \mathrm{O}_{3}-\mathrm{SnO}_{2}$ films, J. Vac. Sci. Technol., A, 2005, 23, 1167-1172.

15 Mineral Commodity Summaries 2005, United States Government Printing office, Washington, DC, 2005, https:// minerals.usgs.gov/minerals/pubs/mcs/2005/mcs2005.pdf.

16 G. Bräuer, B. Szyszka, M. Vergöhl and R. Bandorf, Magnetron sputtering - Milestones of 30 years, Vacuum, 2010, 84, 13541359.

17 P. Lippens, et al., Indium tin oxide (ITO): Sputter deposition processes, in Handbook of Visual Display Technology, ed. J. L. Chen, W. Cranton and M. Fihn, Springer Berlin Heidelberg, New York, U.S., 2011.

18 F. Carreri, A. Sabelfeld, H. Gerdes, R. Bandorf, M. Vergöhl and G. Bräuer, HIPIMS ITO films from a rotating cylindrical cathode, Surf. Coat. Technol., 2016, 290, 65-72.

19 K. Nomura, H. Ohta, K. Ueda, T. Kamiya, M. Hirano and H. Hosono, Thin-film transistor fabricated in single- 
crystalline transparent oxide semiconductor, Science, 2003, 300, 1269-1272.

20 J. Zhou, N. Liu, L. Zhu, S. Yi and Q. Wan, Energy-efficient artificial synapses based on flexible IGZO electric-doublelayer transistors, IEEE Electron Device Lett., 2015, 36, 198200.

21 M. Panthani, V. Akhavan, B. Goodfellow, J. Schmidtke, L. Dunn, A. Dodabalapur, P. Barbara and B. Korgel, Synthesis of CuInS 2 , CuInSe 2 , and $\mathrm{Cu}\left(\operatorname{In}_{x} \mathrm{Ga}_{1-x}\right) \mathrm{Se}_{2}(\mathrm{CIGS})$ nanocrystal "inks" for printable photovoltaics, J. Am. Chem. Soc., 2008, 130, 16770-16777.

22 H. Hsieh, H. Lu, H. Ting, C. Chuang, C. Chen and Y. Lin, Development of IGZO TFTs and their applications to nextgeneration flat-panel displays, J. Inf. Disp., 2010, 11, 160-164.

23 S. Iftimie, C. Tazlaoanu, A. Radu, R. Constantineanu, C. Vancea, N. Korganci, L. Ion and S. Antohe, The spectral response of the photovoltaic cells based on CdS/CdTe heterojunction with different TCO'S, Dig. J. Nanomater. Biostruct., 2014, 9, 213-221.

24 E. Ma, R. Lu and Z. Ming, An efficient rough vacuumchlorinated separation method for the recovery of indium from waste liquid crystal display panels, Green Chem., 2012, 14, 3395-3401.

25 K. Takahashi, A. Sasaki, G. Dodbiba, J. Sadaki, N. Sato and T. Fujita, Recovering indium from the liquid crystal display of discarded cellular phones by means of chlorideinduced vaporization at relatively low temperature, Metall. Mater. Trans. A, 2009, 40, 891-900.

26 Y. He, E. Ma and Z. Xu, Recycling indium from waste liquid crystal display panel by vacuum carbon-reduction, J. Hazard. Mater., 2014, 268, 185-190.

27 J. Yang, T. Retegan and C. Ekberg, Indium recovery from discarded LCD panel glass by solvent extraction, Hydrometallurgy, 2013, 137, 68-77.

28 B. Swain, C. Mishra, H. Hong, S. Cho and S. Lee, Commercial process for the recovery of metals from ITO etching industry wastewater by liquid-liquid extraction: simulation, analysis of mechanism, and mathematical model to predict optimum operational conditions, Green Chem., 2015, 17, 3979-3991.

29 S. Virolainen, D. Ibana and E. Paatero, Recovery of indium from indium tin oxide by solvent extraction, Hydrometallurgy, 2011, 107, 56-61.

30 N. Schaeffer, S. Grimes and C. Cheeseman, Use of extraction chromatography in the recycling of critical metals from thin film leach solutions, Inorg. Chim. Acta, 2017, 457, 53-58.

31 A. LópezDíaz-Pavón, A. Cerpa and F. Alguacil, Processing of indium(III) solutions via ion exchange with Lewatit K-2621 resin, Rev. Metal., 2014, 50, e010.

32 A. Higashi, N. Saitoh, T. Ogi and Y. Konishi, Recovery of indium by biosorption and its application to recycling of waste liquid crystal display panel, J. Jpn. Inst. Met., 2011, 75, 620-625.

33 A. Chagnes, G. Cote, C. Ekberg, M. Nilsson and T. Retegan, WEEE Recycling: Research, Development, and Policies, Elsevier, Saint Louis, U. S., 2016.

$34 \mathrm{H}$. Spandau and H. Hattwig, Studienüber Zinntetrachloridalsionisierendes Solvens, Z. Anorg. Allg. Chem., 1958, 295, 281-290.

35 A. Pray, R. Heitmiller, S. Strycker, V. Aftandilian, T. Muniyappan, D. Choudhury and M. Tamres, Anhydrous metal chlorides, Inorg. Synth., 1990, 28, 321-323.

36 C. Yong, Sulfur dioxide, chlorine, fluorine and chlorine oxides, Solubility data series volume 12, Pergamon press, Oxford, U.K., 1979.

37 J. Stein, M. Kind and E. Schlünder, The influence of $\mathrm{HCl}$ on $\mathrm{SO}_{2}$ absorption in the spray dry scrubbing process, Chem. Eng. J., 2002, 86, 17-23.

38 W. Nimmo, A. Patsias, W. Hall and P. Williams, Characterization of a process for the In-furnace reduction of $\mathrm{NO}_{x}, \mathrm{SO}_{2}$, and $\mathrm{HCl}$ by carboxylic salts of calcium, Ind. Eng. Chem. Res., 2005, 44, 4484-4494. 